\title{
Comments on the Chartres text, with a special attention on
}

\section{vowel-final forms}

\section{David Stifter}

\section{Résumé}

David Stifter analyse plus particulièrement la chute de -s-, car il a déjà étudié ce phénomène de façon approfondie pour la langue gauloise. Pour les noms personnels en -o de la seconde liste, il suggère l'analyse comme datif singulier (comme en latin), les noms en -i étant des datifs ou accusatifs singuliers féminins. Les formes en -us pourraient être des gamonymes, comme dans le Plomb du Larzac. Duti so adogarie est lu comme une formule verbale avec infixation d'un connecteur (e)ti, et d'un pronom so, entre le premier préverbe (du) et les autres préverbes (ad-(u)o-) suivis d'une forme verbale avec désinence réduite (= conjointe).

\section{Abstract}

David Stifter focusses his study on the loss of final -s-, a phenomenon which he has studied in previous studies. For the personal names with final -o in the second list, he suggests a dative singular (as in Latin) or an accusative singular, those with final -i being dative or accusative singular feminine. Forms in -us might be gamonyms, as in the Larzac tablet. Duti so adogarie is analysed as a verbal complex with infixation of a connecting particle (e)ti, and of a pronoun so, between the first preverb (du) and the other preverbs (ad-(u)o-), followed by a conjugated form with a reduced ending (= conjunct).

\section{Citer ce document / Cite this document :}

Stifter David. Comments on the Chartres text, with a special attention on vowel-final forms. In: Etudes Celtiques, vol. 39, 2013. pp. 169-180;

doi : https://doi.org/10.3406/ecelt.2013.2405

https://www.persee.fr/doc/ecelt_0373-1928_2013_num_39_1_2405

Fichier pdf généré le 11/12/2019 


\section{COMMENTS ON THE CHARTRES TEXT, WITH A SPECIAL ATTENTION ON VOWEL-FINAL FORMS}

PAR

David STIFTER

\section{Phonological remarks}

From the point of view of the historical phonology of Gaulish, the most important insight that the Chartres lead-plate allows is about the development of final $-s$. In a recent study (STIFTER 2012a: 533-535), I proposed that in the period that I call Early Gaulish (basically the Gallo-Greek period), word-final $-s$ had been fully retained. Those cases where $-s$ is clearly missing, viz. the endings of the dative plural like $\mu \alpha \tau \rho \varepsilon \beta о ~ v \alpha \mu \alpha v \sigma \kappa \alpha \beta о ~(G-203)<\mathrm{PC} *-b o s,{ }^{2}$ I tried to explain by a morphological restructuring on the analogy to originally $s$-less instrumental plurals in *-bi. I argued that in Middle Gaulish, from the beginning of the Roman Imperial period until roughly the middle of the $2^{\text {nd }}$ c. A.D., $-s$ slowly began to be dropped, first in lower registers of the language, until there was a large-scale weakening of final $-s$ in the latest phases of Gaulish, going hand in hand with the retreat of the language from the public sphere and various high-register functions. The Chartres text, with its display of quite early substantial loss of final $-s$, in conjunction with other newly-found or identified texts (the lead-plate from Rezé (LAmbert \& STIFTER 2012) and the possibly Gaulish texts by L. Cosius (STIFTER 2012b)), has rendered this hypothesis obsolete. Instead, the matter presents itself now thus: the $s$-less dative plurals of the type $\mu \alpha \tau \rho \varepsilon \beta o ~ v \alpha \mu \alpha v \sigma 1 \kappa \alpha \beta o$ are evidence that already in the Early Gaulish period final $-s$ was occasionally weakened and disappeared, first of all in long word-forms like the dative or instrumental plural $<\mathrm{PC} *_{-}(V)$ bos and $*_{-}(V) b i s$. I do no longer believe in an $s$-less instrumental plural *-bi in Proto-Celtic, but it must have been *-bis, as evidenced by the non-lenition following OIr. dative plurals in -(a)ib. The fact that no example of -bis has so far turned up in the Continental Celtic corpus is only due to chance. P.-Y. Lambert (1997: 402405) explained occasional $s$-less spellings of nominatives on Gaulish coin legends as being potentially due to abbreviations caused by the restricted writing space. While

1. I thank Christopher Gwinn and Olivier Piqueron for suggestions about this text. This analysis was written on the basis of the original drawings made by Pierre-Yves Lambert. The drawings published in the earlier part of this article are more recent ones. Due to unfavourable circumstances, I was not able to update the present analysis on the basis of the newer drawings. Therefore, my statements about graphic elements may sometimes be at odds with the published illustrations.

2. Cp. the dative plural in Celtib. -bos, Lep. -pos, and in Noric Latin Vibebos (ILLPRON 642; 643; AE 1975, 662; see Wedenig \& De Bernardo Stempel 2007: 622). 
I acknowledge the fundamental validity of the argument and while I am prepared to regard most of those instances as being abbreviated, in the new light of the Chartres inscription the possibility should not be excluded of having some genuine examples of $s$-loss even among those legends.

The Chartres inscription demonstrates that even as early as the Augustan period loss of final $-s$, perhaps contextually conditioned, was already common. This tendency manifests itself more and more pronouncedly in inscriptions over the following decades, until no $-s$ is left in the late period (e.g. Rezé (L-142), Châteaubleau (L-95)). So far, the two long texts from the middle of the $1^{\text {st }}$ c. A.D., Chamalières (L-100) and Larzac (L-98), blurred the picture by suggesting that $-s$ had remained stable at least until that time, but it emerges now that their retention of final $-s$ is not the rule for Gaulish in the Roman Empire, but rather untypical of the language's development. It is probably best to ascribe their behaviour to the normative influence of Latin school education, ${ }^{3}$ an influence that is undeniable in the case of Larzac with its spellings of $-m$ for final nasals, where the phonetic reality of Gaulish must have been $-n$ or maybe even a nasalised vowel. Gaulish with is propensity towards losing $-s$, perhaps via an intermediate stage of $-h,-z$ or a glottal stop, ${ }^{4}$ may be part of a much further-reaching tendency of languages in Western Europe, encompassing Old Italic languages, Gaulish and Lepontic, the Insular Celtic languages, and Lusitanian. The recent discovery of a third-century West Germanic runic inscription on a comb from Frienstedt (Turingia), reading kaba /kamba/ 'comb' < Proto-Germanic *kambaz < PIE * $\hat{\text { gombos }}$ (SChmid et al. 2010-11), is an invaluable addition to the dossier of $s$-loss, which can now be analysed as an areal linguistic feature of ancient Indo-European languages in the western half of Europe (STIFTER 2010-11).

At first sight, the distribution of forms with and without $-s$ in the Chartres text seems to be random, but a certain ratio, or at least a tendency towards one, emerges under close scrutiny. Naturally, any analysis depends on subjective assumptions about etymologies and the syntactic properties of the involved material, and several of those assumptions may not be shared by other scholars. First, the evidence has to be sifted. Karin Stüber (in this volume) observes that all Roman names in the text are affected by $s$-loss. This observation is interesting, but it may be coincidence and only apparent, unless all those names are actually in the nominative singular (as is indeed maintained by the colleague). If, however, the possibility is granted that Minio Mario, Paulo, Cornuto Cornilio in the second group of names are datives, as will be argued below, they could display the regular Latin endings appropriate to this category; the situation is yet different if these forms are accusatives. The Roman names in $-o$, which are thus a problem of their own, are therefore left aside for the moment. Another set of forms that can be grouped

3. The implication of this assumption is that even in spoken everyday Latin loss or aspiration of $-s$ was more widespread than is manifest from the written record. Perhaps pupils were trained in school education to write final $-s$ in all categories where it belonged according to normative grammar. Since the Gaulish grammatical categories with $-s$, at least the nominal ones, are to a large extent similar to those of Latin, it would have been fairly easy to transfer the rules, learnt for written Latin, also to written Gaulish.

4. For the typology of the loss of $-s$ see KümmeL (2007: 102-104, 114-120). 
together are the apparently verbal forms in -as (A5 + B5 cantipisontas, A9 adgariontas). It is noteworthy that the ending -as, perhaps an enclitic particle (LAMBERT 2008: 462-470), is never written without the $-s$. Either this retention is tied to its status as an enclitic, although particles would be expected to be rather more susceptible to phonetic reduction than fully stressed words, or its $-s$ does not go back to Proto-Celtic $*_{s}$ at all, but to a cluster of dental + sibilant like *ad-s or *-ant-s. The remaining material follows a roughly coherent pattern that may be understood as a kind of 'mutation', comparable in nature to $s$ in French liaison, i.e. it is retained within close phrases, but lost in absolute auslaut. The usual domain of Insular Celtic mutations is also mostly within a phrase, much rarer outside it. Words that stand within a phrase in Chartres tend to retain their -s (A1 Vatumaros Senouiri, A2 Cantognatos Virato, A3 Conbarilos Aberxtobogii, A4 Raros Esuatexti, A6 sondios adgario). Words at phrase boundaries are more prone to loss of -s (A2 Cantognatos Virato_, A6 sondios adgario_, maybe B1 Tasguni Abrestubogiu_), but not all forms conform with this tendency (A8 Tascouipus, B2 Paulo Tasgunias, B4 Lami Eponicnos). Whether and how duti and so fit into this picture depends on one's etymological stance. Finally, the instr. pl. sondiobi is a long word-form. Words of this type display loss of $-s$ already in Early Gaulish, but since this word stands at the end of a phrase, indeed at the end of the entire text, the loss of $-s$ could also be due to the position. Behind long vowels, $-s$ may have been more resilient against loss (A8 Tascouipus, B2 Tasgunias), but the sample is too small to get a reliable picture.

A different rational for the distribution of forms with and without $-s$ has been suggested by Olivier Piqueron: ${ }^{5}$ he, too, made the connection with French liaison and observed that $-s$ is retained before words beginning with a vowel (Conbarilos Aberxtobogii, Raros Esuatexti, sondios adgario, tascouipus adgariontas, Eponicnos eto, cantipisontas eti), before words beginning with a semivowel (Cantognatos Virato), and before words beginning with $s$ (Vatumaros Senouiri, cantipisontas sondios), but is lost before other consonants (Virato_Conbarilos, adgario_duti, Minio_Mario, Mario_Tasguni, Paulo_ Tasgunias, Cornuto_Cornilio, Cornilio_Lami). Tasgunias Cornuto breaks this pattern. However, in order for this rule of sandhi to work, it must be assumed that it operates across phrasal and sentence boundaries, which would be rather unusual.

\section{Al Vatumaros}

Another instance of this name was discovered in 2012 as an epithet of Apollo (Deo Apollin[i] Vatumaro) in a dedicatory inscription, probably $2^{\text {nd }}$ or $3^{\text {rd }}$ c. A.D., from Mesnil-Saint-Nicaise (Somme). ${ }^{6}$ The readily intelligible epithet, which means 'having many prophecies', clearly highlights the vaticinatory aspect of the god. Since in the Chartres inscription the person is introduced with his patronymic, which would be unusual for a theonym, there can be no doubt that Al Vatumaros Senouiri refers to a human person, and not to a god.

5. Email of 28 Oct 2012 on the continentalceltic email list.

6. Press release from 14 Sept 2012, at: http://www.inrap.fr/userdata/c_bloc_file/11/11729/11729_ fichier_CP-LE-MESNIL.pdf (email of 2 Nov 2012 on the continentalceltic email list by Christopher Gwinn). 


\section{A2: Cantognatos}

In addition to Pierre-Yves Lambert's various proposals for the name, *kantugnato- could perhaps be 'song-born' from *kan-tus 'song' (cp. Lat. cantus), cp. the $u$-stem possibly emerging from Cantusus, -a (Bordeaux, CIL XIII, 797; Vichy 13, 1501; Brit., Margam CIIC 407); less likely formed from the passive participle *kanto'sung'. Semantically comparable is Litugenus 'engendered at a festival'.

\section{A5: s.eto, B5: eto}

The reading of these forms is doubtful. On the original drawing (not published in this article), the first of the two looks more like ceto or even cetd. Furthermore, in the same drawing the first vowels do not correspond exactly to the other $e$ 's of the inscription. Whereas elsewhere $e$ is written with two almost perfectly parallel, vertical strokes, in these two instances the letter looks more like a $u$, although the left stroke is not as oblique as with other $u$ 's in this text. So, could this actually be uto?

If this is the same word in both contexts and if it is to be read as eto, this could be $*_{e+t o}(d)$ (the deictic stem $*_{e-}+$ the neuter demonstrative $\left.*_{t o}(d)\right)$, or from $*_{e t}(i)$ $t o(d)$ (connective *eti with syncopated or apocopated $-i+$ neuter demonstrative $* t o(d)$ ). A possible parallel for the $e$ - is furnished by the connector ekue in the Celtiberian inscription from Torrijo del Campo (Vicente Redón \& Ezquerra Lebrón 1999). The second part of ekue is clearly the enclitic * $k^{u} e$ 'and'; the element before it could again be either deictic $* e$ - or syncopated or apocopated *eti 'further, and'. The potentially underlying *etik $k^{\mu}$ has a notable cognate in Gaul. etic (L-13, 98, 100).

More speculatively, eto could be from *he-to $(d)<* s e(d)$-to $(d)(i . e$. , analogical neuter demonstrative $*_{s e}(d)$ 'this' with $s$ - generalised from the animate forms and subsequent proclitic loss of $* s-{ }^{7}+$ neuter demonstrative $\left.* t o(d)\right)$. In the latter case, the strongly and weakly stressed stems $s o-$ and $e-\left(<*_{s e-}\right.$ or $<*_{s o-}$ with vowel reduction) of the demonstrative would stand side by side in the same text. This is reminiscent of such pairs in Gaulish as sinde/indas (L-98) and sondios (Chartres)/onda (L-98).

If the word is $u t o$, this could be $* u+t o(d)$, cp. Gr. oṽ ${ }^{*} \varsigma_{<}<s o-u-t o-$.

\section{A7: adogarie}

Three words on this tablet are read with the ending -ie: A7 adogarie, A9 adgarie and B9 cantigarie. In all three cases, the ending -ie is written with three vertical hastae, |||. The first of these is interpreted as an $i$, the two behind it, in accordance with the writing practice in this tablet, as the cursive character $e$. The ending -ie looks like the Gaulish counterpart of the ending of the Insular Celtic 3sg conjunct. ${ }^{8}$ The first drawing communicated by P.-Y. Lambert shows a horizontal stroke, i.e. $t$ (= adogariti) but nothing can be seen there on the photo. This horizontal stroke has been suppressed in the new drawing, obviously in agreement with the reading adogarie. Although drawing and photograph are not absolutely clear for A7 adogarie and A9 adgarie, at least for $\mathrm{B} 9$ cantigarie the photograph leaves no doubt that there is nothing

7. Like in indas $<*$ sindo- or onda $<*$ sondo-.

8. The possible existence of such forms in Gaulish was postulated by IsAAC (2007: 55). 
above any of the three hastae. On the basis of this third verb it is assumed here that the ending -ie pertains to all three forms. To speak of an ending in the case of -ie is ahistoric because diachronically it is nothing but the plain stem of the present formation. The original ending was either primary *-ti or secondary $*-t$. Secondary $*_{-} t$ could have been simply lost by the general tendency towards loss of final consonants in the language of this text. Primary *-ti would have suffered the same treatment, but had to lose its $*-i$ first. Since final $-i$ patently was not lost across the board in the language of this inscription (B6 eti 'and' still has it), it has to be assumed that $-i$ was lost in specific environments, e.g. in unstressed position as suggested by ISAAC 2007, and the $i$-less allomorph was then generalised from there or extended to other contexts. Adogarie also demonstrates that $*_{i e}$ did not develop into $*_{i}$ in the prehistory of Gaulish. Forms where this appears to be the case, gabi 'take' (L-119), must be due to a later change or to different morphology.

As for the lexical elements of adogarie, Lambert's explanation with *uo looks attractive. Cp. also British where sequences of the preverbs *dī-uno- end up as *dio-, e.g. *dī-uno-dam-> MW diodef.

\section{A7: duti $\cdot$ so $\cdot$ adogarie}

In addition to Lambert's suggestions for duti, another possible analysis needs to be mentioned: perhaps it is the preposition $* d \bar{u}$ 'to, for' $<$ PIE $* d \bar{o}$, used adverbially for 'to this, furthermore, additionally', + the enclitic connector * $(e) t i$, the meaning being 'and to this = also' (cp. German 'und zudem'). For the adverbial use of prepositions with the meaning 'to' as hosts for enclitics compare also Gaul. duci 'and' (L-65; Marichal nr. 13) $<* d \bar{u}+* k e / i$, and the Brit. particle $a$, used for infixing pronouns, explained by Schumacher as adverbially used *ad 'to this' (pers. comm., cited in STIFTER 2012b: 216). The parallel with British may go even further if the following so is analysed as an infixed demonstrative pronoun.

In view of the loss of so many final consonants that Gaulish suffered in the course of its history, so can stand for neuter *sod 'that', but presumably also for masc. nom. sg. *so or *sos, masc. acc. sg. *som, or masc. acc. pl. *sos, referring to the name or names mentioned before. If the preceding duti is not an adverb, but a noun, e.g. a neuter $i$-stem, ${ }^{*} s o(d)$ could agree with it. If $d u t i$ is a feminine accusative $<*_{-i}$, so could be an enclitic, uninflected demonstrative particle like OIr. -so. Under any of these analyses, duti so is best understood as referring to the object of incantation, i.e. to the incantation itself or to the written text. If $s o$ stands for the accusatives $*_{s o m}$ or *sos, it would be a proclitic or infixed (see below) pronoun. If, finally, it is a masc. nom. sg., it either directly continues PIE *so either directly, or *sos with analogical spread of the nominative marker $-s$. As placeholder of the subject, the reference is probably to the immediately preceding adgario 'invoker'.

So is probably identical with demonstrative se in a number of Gaulish texts (L-93, L-98, L-100, plomb de Rezé; see Lambert \& Stifter 2012: 160). Se shows vowel reduction of a weakly stressed element, whereas so, mainly found in texts which are older than those containing se, is still unreduced.

From the point of view of Schrijver's and Schumacher's particle theory (e.g., SchriJver 1997: 147-158, 2011: 76; Schumacher 2004: 90-114, 2011: 170-175), the 
entire phrase in A7 and B9 looks enticingly like the structure ' $\mathrm{P}($ reverb) $+\mathrm{E}$ (nclitic eti) + PRON(oun) + (dependent) V(erbal form)' which they reconstruct for compound verbs:

*dū-(e)ti-so $(\emptyset / \mathrm{m} / \mathrm{d} / \mathrm{s}) \cdot \operatorname{ad}$-uno-garịe $(t)$

as if - mutatis mutandis - OIr. **dos.adgair, but this is far from certain and a variety of alternative analyses are conceivable for this phrase.

\section{A7: Olusami}

I do not think that this form can have a common origin with OIr. ollam 'poet of the highest grade' as suggested by Lambert because - notwithstanding the question of single $v s$. geminate $l$ - the OIr. word cannot simply continue *olusamo-. Instead, raising to **ullam or rather *ulam would be expected in Old Irish (cp. OIr. sinem 'eldest' $<*$ senisamos). Although it is conceivable that the behaviour of * $u$ before $*_{s} / h$ was different from that of $*_{i}$ in that the former did not cause raising (i.e. perhaps *ol(l)usamo- > early lowering *ol(l)ohamo- $>*_{o l}(l)$ ham $)$, such an explanation is less favourable because it requires special pleading. ${ }^{9}$

The morphology of the putative superlative * ${ }^{*}$ olu-samos is unexpected: the PC

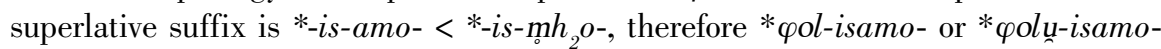
might a priori be expected. Furthermore, *pelh $u$ - 'many' is among the Caland adjectives, so the proto-form *pleh $h_{1} i s$ - $m_{2} h_{2} o$ - should have been inherited in the superlative. ${ }^{10}$ Still, a new, reduced superlative suffix -samo- finds support in formations like Rixama, Uxama, or Venixamus (Saverne, Germania Superior, ILTG 439), Venixsam(us) (Alichamps, Aquitania, CIL XIII, 1357), Venixxam(us) (Poitiers, Aquitania, CIL XIII, 1125), if the latter is from *Uenik(o)-(i) $\operatorname{smo}_{2} o-$. In a formation like *uxs-is-amo$<* u p s(i)$-is-mo $h_{2} o$ - 'highest', *-samo- probably arose through syncope or dissimilation and could have spread from there.

The onomastic basis underlying olusami is perhaps not * $\varphi$ olu- 'many', but rather *ollo/u-. Apart from various names with the first element ollo- 'great, whole' and its allomorph (?) olli-, a by-form with $u$-stem formation has left its traces in the record of female names: Olluna* (Rognes, ILGN-87) and perhaps Olussa (London, RIB-9). Cp. also the epithet of Mars Olloudius (Antibes, CIL XII, 166) and Olludius (Custom Scrubs, RIB-131) (Delamarre 2007: 145). I suggest to see in Olusami a female name derived from the positive stem ollu- onto which the new, reduced superlative suffix *-samo- was attached.

\section{A8: Locuardicni}

The first reading proposed was Loguardicni. On the photograph, the first part of the word looks rather like locn, but this first -n- shows, at the bottom of the left hasta,

9. DIL records the outwardly similar form of the unraised superlative ollom of oll (ZCP 5, $499 \S 8$ ), instead of *uillem, but this is Middle Irish from the late $10^{\text {th }}$ or early $11^{\text {th }}$ century by the poet Máelṡuthain úa Cerbaill $(† 1010)$ and can easily be analogical at that time.

10. Something may have been amiss about this form because in Old Irish, the only modern Celtic language continuing the lexem, the slot of the superlative was left empty in the comparison of $i l$ 'many'. 
a curvature to the right. [This irregular stroke has been omitted as spurious in the edited drawing, in favour of a reading locu; one must however admit the possibility of an extra letter between $c$ and $u$, possibly an X, P.-Y. L.]. At the end of the word, there is no second $n$ visible in the photo, but the letter looks like a $u$, without the left hasta which is necessary for the $n$. Since the picture is somewhat blurred in this area, however, it cannot be excluded that $n$ is correct after all, and this will be assumed in the following. Apart from the greater probability for reading locnardicn/ui on the basis of the available images, there is one more argument that speaks against connecting this word with Irish longbhairdin, as proposed in an earlier part of this article. The native

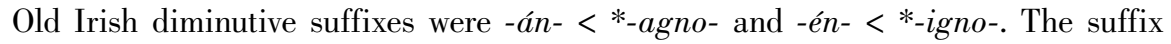
-in-, which became productive in the later Irish language and which is also found in longbhairdin, is not inherited and there is no protoform that could actually produce it in Irish; *-ikno- would have yielded *-én- in Irish. Instead, -in is a loan suffix from Latin, extracted from personal names like Martinus or Augustinus, which was re-interpreted in medieval Irish as having diminutive force under influence from the structurally similar suffixes -án and -én. ${ }^{11}$

\section{A8: Tascouipus}

If *tasco- and *tasgo- reflect two phonologically different etymons in this inscription, 'point' and 'badger' respectively, the name Tascouipus cannot be compared with the Ir. glossatorial term tadg 'poet'. ${ }^{12}$ Ir. Tadg continues *tazgo- < *tasgo- 'badger', but cannot go back to *tasko- 'point' which would have yielded Ir. *tasc. Having said this, it is uncertain that the orthographic variation tasco-/tasgo- necessarily expresses a phonological difference in the first place. In languages without a codified orthographical standard, spelling variation in the same word within a single line or sentence is an all too well-known occurrence, as the study of the medieval Insular Celtic languages abundantly teaches. Tasco-/tasgo-, whether it be one or two different words, is well attested in Celtic anthroponomastics, in monomembric formations and in compounds with the root * $g^{u} a n$ - 'to slay' (cp. DLG 292-293, 2007: 178-179).

The second element -uipus is unclear. Delamarre (2007: 201) records five similar-looking names beginning with Vipo-, but several more can be found in Roman

11. This argument builds on a paper given by Paul Russell at the workshop on Continental Celtic Word Formation in Sept. 2012 in Salamanca.

12. I am altogether very sceptical about accepting $t a d g$ as a genuine word for 'poet' in medieval Ireland. It is known from only two attestations, none of them in a 'normal' context. One is in O'Davoren's Glossary 1540 where it appears in a quotation apparently from a lost poem in Bérla na Filed, the deliberately obscure 'language of the poets' that became popular in Middle Irish. STоKеs (1904: 472), the editor of the glossary, rightly remarks that the quotation anbretha thaidg \{.i. file\} thennal Ulad 'a poet's splendid judgments (are) the torch (?) of Ulaid' could actually contain the popular personal name Tadg, i.e. 'the splendid judgments of Tadg, flame of the Ulaid'. The other occurrence of $t a d g$, this time undoubtedly as a generic noun for 'poet', is in an extremely artificial Modern Irish poem in MS Renehan 70 in the Maynooth Library (Henebry 1901: 378, 381). The author of this poem clearly had access to older glossarial lists of which he made more than ample use, and he did not even attempt at using words that an ordinary person could have understood. The occurrence of $t a d g$ in this specific context proves nothing more than that its author believed that it was an unusual word for 'poet'. It does not prove that this was actually the case. 
inscriptions. In his index of stems, he explicitly equates uipo- with Gaul. uepo- 'word' $<*^{*} e k^{u} O-$, of which it is assumed to be a variant. I am sceptical that these names should be referred to Celtic. Instead, their distribution sheds a different light on the origin of the name element. Q(uinti) Vippi Potiti (CIL XIII, 2306) who is from Lugdunum could conceivably be a Gaul. The same could be true for Vippius Maro Tigridianus (Lomello, Transpadana, CIL V, 6483) and Sollemnis Vipodualis (Saintes, Aquitania, CIL XIII, 1095). But the name actually has a very strong geographical link with ancient Cemenelum, modern Cimiez, a quarter of Nice, which belonged to the province of Alpes Maritimae. Several stones with instances of the name hail from there: C. Vippio Vippi f(ilio) Aberon(i) and Tertia Vippia Vippi f(ilia) (CIL V, 7961), L(ucius) Vippius Ligur (CIL V, 7871), Vippia Clementilla (CIL V, 7962), Vipus Scaevaeif(ilius) (CIL V, 7874). The fact that in CIL V, 7871 the person is called Ligur 'a Ligurian' should warn us against regarding this name as Celtic in the first place. Another inscription from Bobbio in Liguria underlines the Ligurian background: M(arci) Vipponi M(arci) f(ilii) (CIL I, 3399). The evident Ligurian connection suggests that the persons in Lugdunum, Aquitania and the Transpadana could also draw their origin from there.

\section{A7-8: Olusami Locnardicni Tascouipus}

Together the three words could be interpreted as a female personal name, consisting of an individual name in the dative $\left(O l(l) u_{s a m} \bar{a}^{*}\right)$, followed by a patronym in *-ikno- (daughter of Locnardos*) and a form in -us (wife of Tascouipos*). Forms ending in -(i)us, which could potentially be interpreted as gamonyms, occur in the lists of women in Larzac (L-98), where they are always preceded by dona. ${ }^{13}$ For the interpretation of the present text, it must be assumed that the functional element dona could be optionally omitted. Although none of these names finds an exact parallel, some of the elements of which they are made up are known from onomastics elsewhere.

\section{A10: Minio Mario}

These may well be names, but it is striking that the first word reminds one of OIr. min 'small, little' <*minu-, and the second one of Celt. *māro- 'big'. The entire name sounds like 'Mini Maxi', but this is probably coincidence.

\section{B1: Tasguni Abrestubogiu}

Beside being a possible gen. sg. of *Tasgün(i)os, Tasguni could also be the dative of fem. nom. *Tasgu, gen. *Tasgūnos, or of *Tasgün(i) $\bar{a}$. The onomastic suffix - ŭnappears to be strongly at home among female names ${ }^{14}$ (cp. STÜBER 2005: 73; WEDENIG \& De Bernardo Stempel 2007: 622-623), for example in B $\lambda \alpha v \delta$ ooviкovvial (G-146),

13. L-98.1a2-3 ruficna casta dona b[ ] | nonus, 10 paulla dona potiti[us], 12-3 seuera du[xtir] | ualentos dona paulli[ ]us, 15 potita dona primus. The interpretation of these forms as gamonyms is far from certain. It is noteworthy that with the exception of primus, all forms in -us are built on onomastic stems which are otherwise present as female names in Larzac.

14. A great number of such names was collected in the database of Non-Mediterranean Names in Noricum (NNN; at: http://www.univie.ac.at/austria-celtica/personalnames/search.php). A wildcard search for $* u$ will bring up a list of all names. While the list contains male names as well, women are in the vast majority. 
Petrunia (Vienne, CIL XII, 2061), or dat. [C]otuni (Virunum, Noricum, CIL III, 11657). They can be analysed either as on-stems with generalisation of the allomorph $-\bar{u}$ of the nom. sg. throughout the paradigm, or as contaminations of $u h_{2}-$ and on-stems (STIFTER 2012c: §8.4).

The variation $x t \sim s t$, accompanied by metathesis, in A3 Aberxtobogii and B1 Abrestubogiu is startling. Unless they are different words, the substitution of $x$ by the letter $s$ may perhaps be explained by a very palatal pronunciation of the $|\chi|(e . g$. $[\mathrm{c}]\rangle$ $\left.\left[\int\right]\right)$ which could then optionally be rendered by $\langle s\rangle$. The palatal nature of this sound has a genetic or typological parallel in the development of Lat. -ct- via Gallo-Latin - $x t$ to French -it-, e.g. noctem $>$ *noxte $>$ nuit, as well as in Ibero-Romance, e.g. noctem $>$ $*$ noxte $>$ noite (cp. Portuguese, Galego noite, Catalan nit) $>*$ notie $>$ Castillian noche.

\section{The structure of the text}

While there can be no doubt about the first list containing names in the nominative (Vatumaros Senouiri, etc.), the interpretation of the second group (Minio Mario, etc.) runs up against greater difficulties. One reason for this is that these names, including Olusami Locnardicni Tascouipus, if it is a name as argued above, are morphologically ambiguous. In the language of this text final consonants can be dropped: this is clear for $-s$, where the loss is optional, but it is also likely for $-t /-d$ if the verbal forms like adogarie go back to the immediate preform *adogariet (whatever its origin). In the same vein, some particles in -o could represent neuters, i.e. *etod, sod. Given this extensive reduction of final consonants, another important category of consonants lost in word-final position could be nasals. Larzac (L-98) with its wrongly restituted $-m$ is indicative that final nasals may have been weak in Gaulish already in the $1^{\text {st }}$ century A.D., and in late Gaulish texts like Châteaubleau (L-93) this class of sounds is gone completely in final position. As a working hypothesis, this may also be assumed for Chartres. This opens up a wide range of possibilities for determining the syntactic categories of the forms ending in vowels. Furthermore, it is noteworthy that those vowel-final words usually occur after a verb: Olusami Locnardicni Tascouipus after A7 adogarie, Minio Mario, etc. after A9 adgarie. Syntactically they could represent the direct or indirect objects of those words, i.e. accusative or dative respectively. Olusami Locnardicni, Tasguni and Lami could either be datives in $-\bar{l}$, which regularly comes from *-ai, or accusatives in $-i$ going back to earlier *-inn, analogically spread from the $\bar{l}$-stems. Likewise, the male names in -o could be datives, in which case it would be best to assume Latin morphology, or accusatives with -o $<*_{-}$on. Under this hypothesis, Minio, Paulo and Cornuto can be analysed to stand in the same case as Tasguni and Lami and no recourse needs to be taken to an inverted order of individual names and patronyms. ${ }^{15}$ As a corollary, Bl Abrestubogiu has to be read as the gamonym *Abrestubogius referring to feminine *Tasg $\bar{u}$ or *Tasgun(i) $\bar{a}$, just like Tascouipus qualifies feminine Olusami in the analysis above. The apparent

15. On the other hand, if those names do stand in the nominative and represent the victims of the invocation, the inverted order of patronymic + idionym may have something to do with the invocation, i.e. a disturbance of the natural order. 
nominative B4 Eponicnos is a thorn in the flesh of this hypothesis because it does not fit syntactically. Maybe it has to be emended to the gamonym *Eponicnus.

Depending on how the vowel-final forms are interpreted, several different structural analyses of the clauses are viable. If the forms are accusatives which express the direct object of ad(o)garie, the preceding so is best regarded as a nominative referring to the subject. Duti is then an adverb or conjunction. ${ }^{16}$ If the vowel-final forms are datives and thus the indirect object of ad(o)garie, various possibilities open up: duti could still be an adverb or conjunction and so either a pronominal reference to the object ('it') ${ }^{17}$ or to the subject ('he') ${ }^{18}$. In the former case, the subject would find no overt realisation. Finally, duti so could be the object $;{ }^{19}$ so could be a demonstrative accompanying it or it could refer to the subject. ${ }^{20}$

16. A tentative translation of the first of these sentences in order to illustrate the envisaged structure: 'furthermore/then (duti) he (so) accuses/enchants (adogarie) Olusama daughter of *Locnardos wife of *Tascouipos'. The second sentence can be construed parallel to this.

17. 'Furthermore/then (duti) he accuses (adogarie) it (so) to/on Olusama daughter of *Locnardos wife of *Tascouipos' (= 'accuses her of it').

18. 'Furthermore/then (duti) he (so) makes an accusation/enchantment (adogarie) to/on Olusama daughter of *Locnardos wife of *Tascouipos.'

19. 'He invokes (adogarie) this (so) duti to/on Olusama daughter of *Locnardos wife of *Tascouipos.'

20. 'He (so) invokes (adogarie) the duti to/on Olusama daughter of *Locnardos wife of *Tascouipos.' 


\section{BIBLIOGRAPHY}

Delamarre 2007 - Xavier Delamarre, Nomina Celtica Antiqua Selecta Inscriptionum (Noms de personnes celtiques dans l'épigraphie classique), Paris, Éditions Errance, 2007.

$D L G$ - Xavier Delamarre, Dictionnaire de la langue gauloise. Une approche linguistique du vieux-celtique continental, préface de Pierre-Yves Lambert, $2^{\mathrm{e}}$ édition revue et augmentée, Paris, Éditions Errance, 2003.

Henebry 1901 - Richard Henebry, “The Renehan “Air”, Zeitschrift für celtische Philologie 3, 1901, pp. 377-382.

IsAAC 2007 - Graham Isaac, "A new conjecture on the origins of absolute and conjunct flexion”, Ériu 57, 2007, pp. 49-60.

Kümmel 2007 - Martin J. Kümmel, Konsonantenwandel. Bausteine zu einer Typologie des Lautwandels und ihre Konsequenzen für die vergleichende Rekonstruktion, Wiesbaden, Reichert, 2007.

LAMBERT 1997 - Pierre-Yves Lambert, "Gaulois tardif et latin vulgaire", Zeitschrift für celtische Philologie 49/50, 1997, pp. 396-413.

Lambert 2008 - Pierre-Yves Lambert, "Une particule gauloise -as?", Palaeohispanica 8, 2008, pp. 459-470.

Lambert \& Stifter 2012 - Pierre-Yves Lambert et David Stifter, "Le plomb gaulois de Rezé", Études Celtiques 38, 2012, pp. 139-164.

Schмid et al. 2010-11 - Christoph Schmidt, Robert Nedoma, Klaus Düwel, "Die Runeninschrift auf dem Kamm von Frienstedt, Stadt Erfurt”, Die Sprache 49/2, 2010-11 (2012), pp. 123186.

Schrijver 1997 - Peter Schrijver, Studies in the History of Celtic Pronouns and Particles [= Maynooth Studies in Celtic Linguistics 2], Maynooth, Department of Old Irish, 1997.

Schrijver 2011 - Peter Schrijver, "Old British”, in: Brythonic Celtic. Britannisches Keltisch. From Medieval British to Modern Breton. Edited by Elmar Ternes [= Münchner Forschungen zur historischen Sprachwissenschaft 11], Bremen, Hempen Verlag, 2011, pp. 1-84.

Schumacher 2004 - Stefan Schumacher, Die keltischen Primärverben. Ein vergleichendes, etymologisches und morphologisches Lexikon. Unter Mitarbeit von Britta Schulze-Thulin und Caroline aan de Wiel [= Innsbrucker Beiträge zur Sprachwissenschaft 110], Innsbruck, Institut für Sprachen und Literaturen der Universität Innsbruck, 2004.

Schumacher 2011 - Stefan Schumacher, "Mittel- und Frühneukymrisch", in Brythonic Celtic. Britannisches Keltisch. From Medieval British to Modern Breton. Edited by Elmar Ternes [= Münchner Forschungen zur historischen Sprachwissenschaft 11], Bremen, Hempen Verlag, 2011, pp. 85-235.

STIFTER 2010-2011 - David Stifter, "Schwund von auslautendem $-s$ als westeuropäische areale Erscheinung", Die Sprache 49/2, 2010-11 (2012), pp. 187-193.

Stifter 2012a - David Stifter, "Lenition of *s in Gaulish?" in The sound of Indo-European. Phonetics, Phonemics and Morphophonemics, edited by Benedicte Nielsen Whitehead, Thomas Olander, Birgit Anette Olsen and Jens Elmegård Rasmussen, Copenhagen, Museum Tusculanum Press, 2012, pp. 523-544. 
STIFTER 2012b - David Stifter, "New early second-century Gaulish texts from La Graufesenque (L-143a-c)", Keltische Forschungen 5, 2012, pp. 197-227.

STIFTer 2012c. - David Stifter, "On the linguistic situation of Roman-period Ig", in Personal

Names in the Western Roman Empire. Cambridge (UK), 16-18 September 2011, edited by Torsten Meißner, Berlin, Curach Bhán Publications 2012, pp. 247-265.

Sтокеs 1904 - Whitley Stokes, “O’Davoren's Glossary”, Archiv für celtische Lexikographie 2, 1904, pp. 197-504.

STÜвеR 2005 - Karin Stüber, Schmied und Frau. Studien zur gallischen Epigraphik und

Onomastik [= Archaeolingua Series Minor 19], Budapest, Archaeolingua, 2005.

Vicente Redón \& Ezquerra Lebrón 1999 - Jaime D. Vicente Redón and Beatriz Ezquerra

Lebrón, "El bronce celtibérico de Torrijo del Campo (Teruel)", in Pueblos, lenguas y escrituras en la Hispania prerromana. Actas del VII Coloquio sobre Lenguas y Culturas Paleohispánicas (Zaragoza, 12 a 15 de marzo de 1997). Ed. por F. Villar y F. Beltrán [= Acta Salmanticensia. Estudios filológicos 273], Salamanca, Ediciones Universidad de Salamanca, 1999, pp. 581-594.

Wedenig \& De Bernardo Stempel 2007 - Reinhold Wedenig und Patrizia de Bernardo Stempel,

"Keltisches in norischen Personennamen", in Kelten-Einfälle an der Donau. Akten des 4. Symposiums deutschsprachiger Keltologinnen und Keltologen, herausgegeben von Helmut Birkhan, Wien, Verlag der Österreichischen Akademie der Wissenschaften, 2007, pp. 619-630. 